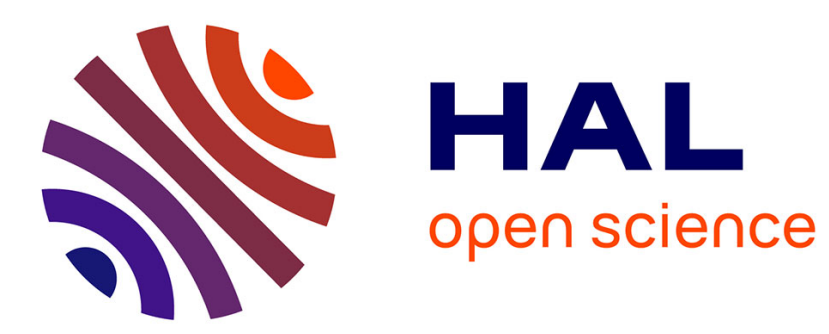

\title{
On the influence of the exciton-blocking layer on the organic multilayer cells properties
}

\author{
A. S. Yapi, L. Toumi, Y. Lare, G. M. Soto, Linda Cattin, K. Toubal, A. \\ Djafri, M. Morsli, A. Khelil, M. A. del Valle, et al.
}

\section{- To cite this version:}

A. S. Yapi, L. Toumi, Y. Lare, G. M. Soto, Linda Cattin, et al.. On the influence of the excitonblocking layer on the organic multilayer cells properties. European Physical Journal: Applied Physics, 2010, 50 (3), pp.30403. 10.1051/epjap/2010062 . hal-00593673

HAL Id: hal-00593673

https://hal.science/hal-00593673

Submitted on 17 May 2011

HAL is a multi-disciplinary open access archive for the deposit and dissemination of scientific research documents, whether they are published or not. The documents may come from teaching and research institutions in France or abroad, or from public or private research centers.
L'archive ouverte pluridisciplinaire HAL, est destinée au dépôt et à la diffusion de documents scientifiques de niveau recherche, publiés ou non, émanant des établissements d'enseignement et de recherche français ou étrangers, des laboratoires publics ou privés. 


\section{On the influence of the exciton-blocking layer on the organic multilayer cells properties}

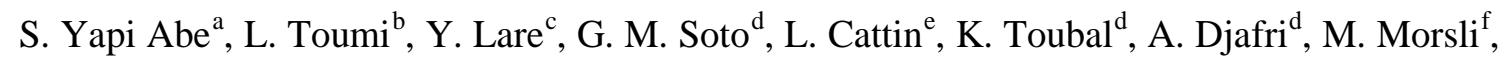
A. Khelil ${ }^{\mathrm{b}}$, M.A. del Valle ${ }^{\mathrm{c}}$, J.C. Bernède ${ }^{\mathrm{f} *}$.

a- Université de Cocody, UFR SSMT 22 BP 258 Abidjan, Côte d'Ivoire.

b- Université de Oran Es-Sénia, LPCM2E, Oran, Algérie,

c-Université de Lomé, Laboratoire

d- Laboratorio de Polímeros, Facultad de Química, PUCC, Correo 22, Santiago, Chile.

e- Université de Oran Es-Sénia, LSOA, Oran, Algérie,

f- LAMP, Université de Nantes, Nantes Atlantique Université de Nantes, Faculté des Sciences et des Techniques, 2 rue de la Houssinière, BP 92208, Nantes, F -44000 France.

e- IMN-CNRS, Université de Nantes, Nantes Atlantique Universités, 2 rue de la Houssinière, BP 92208, Nantes, F-44000 France.

Abstract: The performances of organic photovoltaic cells based on the layer couple electron donor/electron acceptor (ED/EA) are significantly improved when an exciton blocking layer (EBL) is inserted between the organic acceptor and the cathode. A new material, the (Z)-5-(4chlorobenzylidene)-3-(2-ethoxyphenyl)-2-thioxothiazolidin-4-one, that we called (CBBTZ), has been synthesized, characterized and probed as EBL. The energy levels corresponding $t o$ the highest occupied molecular orbital (HOMO) and the lowest unoccupied molecular orbital (LUMO) of the CBBTZ have been determined from the first oxidation and reduction potential respectively, using cyclic voltametric $(\mathrm{CV})$ measurements. From $\mathrm{CV}$ curves, CBBTZ in dichloromethane showed a one electron reversible reduction and oxidation waves. The values of its HOMO and LUMO have been estimated to be $6.42 \mathrm{eV}$ and $3.42 \mathrm{eV}$ respectively. Such values show that CBBTZ could be probed as EBL in organic solar cells $b$ ased on the ED/EA couple copper phthalocyanine $(\mathrm{CuPc}) /$ fullerene $\left(\mathrm{C}_{60}\right)$. The photovoltaic solar cells have been obtained by sequential deposition under vacuum of the different films. The different thin film thicknesses were measured in situ by a quartz monito r. Multilayer solar cells $\mathrm{ITO} / \mathrm{Au} / \mathrm{CuPc} / \mathrm{C}_{60} / \mathrm{EBL} / \mathrm{Al}$ have been probed, where $\mathrm{EBL}$ is the aluminium tris $(8$ hydroxyquinoline) ( $\mathrm{Alq}_{3}$ ), the CBBTZ, the 2-(4-byphenylyl)-5-(4-tert-buthylphenyl)-1,3,4oxadiazole (butyl PBD) or the bathocuproine (BCP). The optimum film thickness is $8-9 \mathrm{~nm}$ whatever the EBL used. When obtained in the same run, the averaged efficiency of the cells using the CBBTZ is of the same order of magnitude than that obtained with BCP and higher 
than that achieved with $\mathrm{Alq}_{3}$ or butyl PBD. It is shown by XPS study that some aluminium of the cathode is present in the buffer layer. This aluminium could justify the ability of the electrons to cross the insulating exciton blocking layer thick of $9 \mathrm{~nm}$.

Keywords: Organic solar cell, exciton blocking layer, XPS, buffer layer, cyclic voltammetry, electrochemistry.

PACS: 68.35.-p; 78.56.-a;

*Corresponding author: J.C. Bernède, Tel : 332511255 30, Fax : 332511255 28,

E-mail: jean-christian.bernede@univ-nantes.fr

\section{Introduction}

Although impressive progresses have been done during last years, the organic solar cells (OSC) efficiency is still in need of improvement. A general problem in organic electrical devices is the transport of charge carriers at the interfaces electrode/organic material. Interfacial phenomena represent a challenge and important area in organic devices science and technology. A variety of interfacial treatments have been applied to both the cathode/organic and the anode/organic interfaces, different more or less thin buffer layers have been placed at these interfaces, resulting in varying degrees of devices improvement in term of charge exchange [1].

For vapor deposited multilayer structure OSCs, a significant increa se in efficiency occurs upon the insertion of an interfacial layer, often called "exciton blocking layer" (EBL) [2] between the cathode and the electron acceptor film. Bathocuproine (BCP) is often used as exciton blocking buffer layer [3]. However, with ti me, BCP tends to crystallize, which induces some OSCs performance degradation [4]. So others materials have been probed as EBL such as more conductive materials [5] or more stable such as the aluminium tris(8 hydroxyquinoline) $\left(\mathrm{Alq}_{3}\right)[4,6-7]$.

The material used as EBL should be transparent across the solar spectrum acting as a spacer between the photoactive films and the cathode. It must transport charge, allowing low series resistance. Its HOMO (highest occupied molecular orbital) and LOMO (lowest 
unoccupied molecular orbital) values should permit the buffer layer to act as an efficient exciton blocking layer.

In the present paper, after its characterization, a new material, the (Z)-5-(4chlorobenzylidene)-3-(2-ethoxyphenyl)-2-thioxothiazolidin-4-one, that we called (CBBTZ) (scheme 1), has been probed. For comparison and in order to try improving the understanding of the EBL action, we have probed different others organic materials, among them the aluminium tris(8-hydroxyquinoline) ( $\left.\mathrm{Alq}_{3}\right)$, the 2-(4-byphenylyl)-5-(4-tert-buthylphenyl)1,3,4-oxadiazole (butyl PBD) or the bathocuproine (BCP). It is shown that the optimum thickness of the different EBL used during this work is systematically around $8-9 \mathrm{~nm}$. Good results, of the same order of magnitude than thos e obtained with BCP have been achieved with CBBTZ. The high short circuit current value measured can be explained by al diffusion into the EBL. The difference in the cells efficiencies from one EBL to another one is discussed in terms of band structure and interface properties, results as good as those obtained with BCP are achieved with the new EBL, the CBBTZ.

\section{Experimental}

\subsection{CBBTZ experimental characterization:}

The structure of CBBTZ is presented in scheme 1.

The HOMO and LUMO of the CBBTZ have been estimated by cyclic voltammetry (CV). The experimental method to carry out the CV has been previously described [ 8].

A three-compartment three-electrode glass cell was used to carry out this experiment. A Pt disc of $0.07 \mathrm{~cm}^{2}$ geometric area was used as work electrode. A Pt gauze of large geometrical area and a $\mathrm{Ag} / \mathrm{AgCl}$ in tetramethylammonium chloride $\left(\mathrm{Me}{ }_{4} \mathrm{NCl}\right)$ were used as counter and reference electrodes, respectively. All the potentials are referred to the saturated calomel electrode (SCE) [9].

Dichloromethane anhydrous $\left(\mathrm{CH}_{2} \mathrm{Cl}_{2}\right)$ and tetrabutylammonium hexafluorophosphate $\left(\mathrm{TBAPF}_{6}\right)$ were used as solvent and support electrolyte, respectively. A solution of CBBTZ $0.001 \mathrm{~mol} \cdot \mathrm{L}^{-1}, \mathrm{TBAPF}_{6} 0.1 \mathrm{~mol} \cdot \mathrm{L}^{-1}$ and $\mathrm{CH}_{2} \mathrm{Cl}_{2}$ was used in this experiment.

To warrant a minimum content of water (below $0.5 \mathrm{mmol} \cdot \mathrm{L}^{-1}$ ) $\mathrm{CH}_{2} \mathrm{Cl}_{2}$ was stored under dry argon atmosphere, on molecular sieves $(3 \AA)$, and handled with a syringe.

The potential range from 0 to $2.5 \mathrm{~V}$ and potential range from -1.5 to $0 \mathrm{~V}$ (scan rate $0.008 \mathrm{~V} \cdot \mathrm{s}^{-1}$ ) were used to determine the HOMO and the LUMO, respectively.

The experiment was performed on a Radiometer (Model PGP -201) potentiostat connected to a computer for data acquisition and analysis. 
Optical measurements were carried out with a Cary 2300 spectrophotometer from 0.8 $\mu \mathrm{m}$ to $0.4 \mu \mathrm{m}$.

X-ray photoelectron spectroscopy (XPS) measurements were performed to investigate the CBBTZ after deposition in thin film and the possible $\mathrm{Al}$ cathode diffusion into the buffer layer. XPS analyses were performed with a magnesium X -ray source $(1253.6 \mathrm{eV})$ operating at $10 \mathrm{kV}$ and $10 \mathrm{~mA}$. During the measurements the vacuum was $10^{-7} \mathrm{~Pa}$, the pass energy for high resolution spectra was $50 \mathrm{eV}$. The quantitative studies were based on the determination of each peak after subtraction of s-shaped background. For the quantitative study, the sensitivity factors $\mathrm{s}$, given by the manufacturer were : $\mathrm{C} 1 \mathrm{~s}, \mathrm{~s}=0.6 ; \mathrm{N} 1 \mathrm{~s}, \mathrm{~s}=0.36 ; \mathrm{O} 1 \mathrm{~s}, \mathrm{~s}=0.6 ; \mathrm{Cl} 2 \mathrm{p}, \mathrm{s}=$ $0.58 ; \mathrm{S} 2 \mathrm{p}, \mathrm{s}=0.44$ and $\mathrm{A} 12 \mathrm{p}, \mathrm{s}=0.146$. The samples were grounded with conductive paste to decrease the charge effect. To measure this charge effect on the measured binding energies the spectra were referred to the $\mathrm{C} 1 \mathrm{~s}$ line. The spectrometer was calibrated at $285 \mathrm{eV}$ for this line.

In order to check the diffusion, or not, of aluminium into the exciton blocking layer, sample designed $(1 \mathrm{~cm} \times 1.2 \mathrm{~cm})$ for XPS have been prepared in parallel with classical solar cells. After aluminium deposition the $\mathrm{Al}$ cathode upper layer has been taken off from the solar cell by simple "scotch tape test". Indeed such process allows taking off only the metal film, since experiments have shown that, when performing the scotch tape test to organic solar cells, the adhesion of the Al electrode to the organic under-layer fails. Then the aluminium diffusion into the buffer layer has been estimated by recording successive XPS spectra after each argon ion etching. Argon sputtering was accomplished at pressures of less than $510^{-4} \mathrm{~Pa}$, a $10 \mathrm{~mA}$ emission current and a $5 \mathrm{kV}$ beam energy using an ion gun. Using these experimental conditions, the ion current density was $18 \mu \mathrm{A} \mathrm{cm}^{-2}$. The Ar+ ion could etch the entire sample surface.

\subsection{Organic cells realisation and characterisation}

The device structure used in this study was:

$$
\text { ITO/Au }(0.5 \mathrm{~nm}) / \mathrm{CuPc}(35 \mathrm{~nm}) / \mathrm{C}_{60} / \mathrm{BL} / \mathrm{Al}
$$

The multi-layer heterojunction structure has indium tin oxide (ITO) as bottom anode. We have shown that the hole barrier often present at the interface ITO/organic electron donor can be systematically avoided by evaporating an ultra thin gold layer between the ITO and the organic $[10,11]$, therefore ITO/Au $(0.5 \mathrm{~nm})$ anode structures have been used. 
Since the aim of this work is the study of the EBL between the electron acceptor and the cathode, the cells are based on the well known heterojunction: copper pthtalocyanine $(\mathrm{CuPc}) /$ fullerene $\left(\mathrm{C}_{60}\right)$.

The ITO coated glass substrates used in this study were commercially obtained from the SOLEMS. Since ITO covered the whole glass substrates, some ITO must be removed to obtain the under electrode. After masking a broad band of $30 \mathrm{~mm}$ by $20 \mathrm{~mm}$, the ITO was etched by using $\mathrm{Zn}$ powder $+\mathrm{HCl}(\mathrm{N} / 10)$ [12]. After carefully scrubbing, with alcohol and then soap, these substrates were rinsed in running deionised water. Then the substrates were dried and immediately loaded into a vacuum chamber $\left(10^{-4} \mathrm{~Pa}\right)$.

The chemical products $\left(\mathrm{CuPc}, \mathrm{C}_{60}, \mathrm{BCP}, \mathrm{Alq}_{3}\right.$, butyl-PBD) have been provided by Aldrich. The CBBTZ has been synthesized by the LSOA team (Université d'Oran Es-Sénia). The synthesis of the CBBTZ is described in a previous paper [13].

The chemical products were used without any purification. It has been shown that, using the same charge in the evaporation crucible, there is an "auto purification" of the product after approximately five thin film depositions. The main impurity in CuPc-95\% is $\mathrm{H}_{2} \mathrm{Pc}$ [14]. The melting point of $\mathrm{H}_{2} \mathrm{Pc}\left(300^{\circ} \mathrm{C}\right)$ being less than that of $\mathrm{CuPc}\left(360^{\circ} \mathrm{C}\right), \mathrm{H}_{2} \mathrm{Pc}$ is removed from the source during the initial deposits [15]. Therefore, our experiment has shown that, in the experimental conditions used in the laboratory, the deposition of $300 \mathrm{~nm}$ of $\mathrm{CuPc}$, before cells realisation, are necessary to be sure to achieve performing devices.

All the thin films of the structures have been deposited in the same run in a vacuum of $10^{-4} \mathrm{~Pa}$. The thin film deposition rates and thickness were estimated in situ with a quartz monitor. The deposition rate and final thickness were $0.05 \mathrm{~nm} / \mathrm{s}$ and $35 \mathrm{~nm}$ in the case of $\mathrm{CuPc}, 0.05 \mathrm{~nm} / \mathrm{s}$ and.40 $\mathrm{nm}$ in the case of $\mathrm{C}_{60}$. These thicknesses have been chosen after optimisation.

In the case of the exciton blocking layer, the known optimum thicknes s has been used, 8-9 $\mathrm{nm}$ for $\mathrm{BCP}[3]$ and $\mathrm{Alq}_{3}[6]$, while it has been varied from 5 to $15 \mathrm{~nm}$ in the case of the new materials CBBTZ and butyl-PBD.

After organic thin film deposition, the aluminium top electrodes, through a mask with $2 \mathrm{~mm} \times 8 \mathrm{~mm}$ active areas, and an approximately $100 \mathrm{~nm}$ encapsulating layer of amorphous selenium (Se-a) were thermally evaporated, without breaking the vacuum. The selenium protective coating layer has been proved to be efficient to protect the under layers from oxygen and water vapour contamination [16], at least during the first hours of room air exposure [7]. 


\section{Results}

\subsection{CBBTZ characterization}

The HOMO and LUMO values of CBBTZ have been measured following the process described in the experimental section. From $\mathrm{CV}$ curves (f igure 1), $\mathrm{CBBTZ}$ in $\mathrm{CH}_{2} \mathrm{Cl}_{2}$ show the oxidation (figure 1 (a)) and reduction (figure 1 (b)) waves. The energy levels (in electron volts, eV), i.e. HOMO and LUMO energies of CBBTZ can be determined adding $4.4 \mathrm{eV}$ to values of the first oxidation $\left(\mathrm{E}_{p}\right)$ and reduction $\left(\mathrm{E}_{n}\right)$ potentials, respectively [17]. Therefore, $\mathrm{E}_{\mathrm{HOMO}}=-e\left(\mathrm{E}_{p}+4.4\right)$, and $\mathrm{E}_{\mathrm{LUMO}}=-e\left(\mathrm{E}_{n}+4.4\right)$.

The potential difference $\mathrm{Eg}=\mathrm{E}_{\mathrm{LUMO}}-\mathrm{E}_{\mathrm{HOMO}}$ can be used to estimate the energy gap $\left(\mathrm{E}_{\mathrm{g}}\right)$ of the dye.

Relatively to the vacuum level the energy values of HOMO a nd LUMO levels are $-6.42 \mathrm{eV}$ and $-3.42 \mathrm{eV}$ respectively. Therefore the band gap estimated from the electrochemical measurements is $3.0 \mathrm{eV}$.

In figure 2 the transmission spectrum of a thin CBBTZ film deposited by sublimation onto a glass substrate is re ported. It can be seen that the transmission curve exhibits threshold energy around $2.95 \mathrm{eV}$. It can be estimated roughly that this threshold energy corresponds to the optical band gap of CBBTZ, which is in good agreement with electrochemical study.

In figure 3 XPS spectra of the surface of a CBBTZ are presented. We have proceeded to a decomposition of the measured peaks into different components. The curve fitting programs, which include background removal, peak integration and area measurement, quantification, curve synthesis, and peak fitting, permit the variation of parameters such as the Gaussian/Lorentzian ratio, the full width at half maximum (FWHM), and the position and the intensity of the contributions. These parameters were optimized by the curv e fitting programs to obtain the best fit.

It is well known that the binding energy of the peaks increases with the resistivity of the analysed sample, which is called $\Delta \mathrm{E}$ the charge effect. With the spectrometer used, the carbon-carbon binding energy refe rence is $285 \mathrm{eV}$, while the value deduced from figure $3 \mathrm{a}$ is $287 \mathrm{eV}$ which shows that $\Delta \mathrm{E}=2 \mathrm{eV}$. In order to compare the binding energies of the different components to values given in the handbooks, $\Delta \mathrm{E}$ should be systematically deduced from the values estimated from figure 3 . One can see in figure $3 \mathrm{a}$ that the carbon peak $\mathrm{C} 1 \mathrm{~s}$ can be decomposed into 6 components. As said above, the peak situated at $285 \mathrm{eV}$ corresponds to $\mathrm{C}$ $\mathrm{C}$ bonds. The peak situated at $286 \mathrm{eV}$ can be attributed to $\mathrm{C}-\mathrm{N}, \mathrm{C}_{\text {aromatic }}-\mathrm{Cl}$. The third peak $(286.8 \mathrm{eV})$ can corresponds to $\mathrm{S}-\mathrm{C}=\mathrm{S}, \mathrm{C}-\mathrm{O}-\mathrm{C}$ and also to some $\mathrm{C}-\mathrm{OH}$ surface contamination. 
Then the fourth peak situated at 288 corresponds to $\mathrm{C}=\mathrm{O}$ while the two last small peaks can be attributed to surface contamination $\left(\mathrm{COOH}, \mathrm{CO}_{\mathrm{x}}\right)$. Before XPS analysis the CBBTZ film has been kept some time in room air, which justifies this surface contamination. The O1s peak corresponds to two components, the $\mathrm{C}=\mathrm{O}(532 \mathrm{eV})$ and $\mathrm{C}-\mathrm{OH}, \mathrm{C}-\mathrm{O}-\mathrm{C}(533.3 \mathrm{eV})$ bonds. After charge effect subtraction, the binding energies of $\mathrm{S} 2 \mathrm{p}, \mathrm{N} 1 \mathrm{~s}, \mathrm{Cl} 2 \mathrm{p}$, correspond to the covalent bonds of the CBBTZ. It can be concluded that, after sublimation in vacuum the CBBTZ molecule has been preserved.

\subsection{Organic solar cells study}

The characterization of the CBBTZ has shown that it exhibits the properties ex pected to be used as exciton blocking layer in organic solar cells.

In a first time, the optimum CBBTZ and butyl-PBD exciton blocking layer thickness has been determined by probing different devices with a EBL thickness varying from $5.5 \mathrm{~nm}$ to $15 \mathrm{~nm}$. The example of CBBTZ is given in figure 4 . It can be seen that the optimum thickness $(7-8 \mathrm{~nm})$ is similar to that of the others EBL used in the present work $\left(\mathrm{Alq}_{3}\right.$ and $\mathrm{BCP}),[3,7]$.

In a second time, we have studied the results achieved with different EBL in solar cells deposited in the same run, using the optimum thickness. The results have been checked by successive runs.

Typical results are presented in table 1 and figure 5. It app ears that the introduction of an exciton blocking layer at the interface $\mathrm{C}_{60} / \mathrm{Al}$ permits achieving better energy conversion efficiency, the best results being obtained, with CBTTZ and BCP. More precisely, the fill factor and the short circuit current of these cells are significantly improved.

After J-V characterization, we have checked the possible aluminium diffusion into the EBL by XPS. It has been estimated by recording successive XPS spectra after each argon ion etching. The etching speed in the experimental conditions used has been estimated to be around $0.8-1.0 \mathrm{~nm} / \mathrm{min}$.

Two typical EBL, the CBBTZ (high Jsc and FF) and the butyl-PBD (smaller Jsc and FF), have been studied. It is well known that ion etching of organic materials induces some chemical bonds breaking and that the etching rate of carbon is smaller than that of others atoms such as oxygen, nitrogen, chlorine, which implicates some surface graphitisation effect of the surface of the sample. Therefore any atomic composition profile deduced from organic material etching should be interpreted with precaution. However if absolute relative values are misleading, the profile allows to check the presence or not of aluminium, into the organic 
material and its relative atomic concentration variation from one sample to another one. Moreover, in the case of CBBTZ, it is easy to chec $k$ the presence, or not, of the EBL after the "scotch tape test" by looking for $\mathrm{Cl}$ and $\mathrm{S}$. Figure 6a shows that, after the scotch test, the $\mathrm{EBL}$ is still present onto the sample since $\mathrm{Cl}, \mathrm{N}$ and $\mathrm{S}$ are detected. Moreover, figure 6 one can see that there is some Al diffusion into the EBL during cathode deposition. Since the etching rate is around $1 \mathrm{~nm} / \mathrm{s}$ and the thickness of the EBL is $9 \mathrm{~nm}$, it can be said that aluminium is present all over its thickness. It appears that the maximum atomic concentration of $\mathrm{Al}$ is embedded in the bulk of the EBL.

In figure 7, the Al2p peak corresponds to two contributions. The first one, knowing that there is a charge effect of $2 \mathrm{eV}$, is situated at $71.3 \mathrm{eV}$. It can be attributed to the metallic aluminium. The second one situated at $73.4 \mathrm{eV}$ corresponds to alumina. The A12p peak decomposition shows that there is one third of metallic aluminium and two third of alumina.

\section{Discussion}

The slopes at the short circuit point and at the open circuit voltage are the inverse values of the shunt resistance and the series resistance of the equivalent circuit scheme of a solar cell respectively [18]. The values deduced from these approximations are reported in table 2. The best EBL (BCP and CBBTZ) correspond to the cells with the smallest series resistance (Rs) and highest shunt resistance (Rsh). The high value of Rsh means that the homogeneity of the interface is improved by these EBL, avoiding shunt paths through pinholes, grain boundaries... The small value of Rs shows that these EBLs allow achieving a low contact resistance between the cathode and the electron acceptor.

In an organic solar cell, after photon absorption and exciton formation, this exciton should reach a dissociation site i.e. usually a donor/acceptor interface. Exciton diffusio $n$ range in organic materials before desexcitation is only $10-20 \mathrm{~nm}$, while the thickness of the absorbing organic film should be around 100nm to absorb efficiently the solar light.

It has been shown that one way for circumventing the diffusion length limit ation is to use cells with multiple interfaces. Peumans et al. [3] have shown that the introduction of a thin large band gap organic material allows improving significantly the device performances. They called electron blocking layer (EBL) this thin film, because its band gap is substantially larger than that of the organic donor and acceptor, which block excitons in the organic semiconducting layer far from the cathode avoiding any quenching effect at the interface cathode/organic. For vapor deposited multiplayer structures, a significant increase in efficiency occurs upon the insertion of the exciton blocking layer interfacial layer, between 
the cathode and the electron acceptor film. Bathocuproine (BCP) is often used as exciton blocking buffer layer [3].

Accordingly to the above discussion, the results of the present work can be, at least partly, explained by the band scheme of the different structures used. To act as efficient exciton blocking layer, its HOMO absolute energy value should be greater than the HOMO value of the electron accepting organic layer. As it can be seen in figure 8 and table 3, CBBTZ should be more efficient than $\mathrm{Alq}_{3}$. It can prevent exciton quenching at the acceptor/cathode interface and therefore justifies the higher short circuit current and fill factor values. However this is true with $\mathrm{Alq}_{3}$ but it does not work in the case of butyl-PBD (table 3). Therefore exciton blocking effect related to the HOMO and LUMO values of the buffer layer is not the only effect of this layer.

Indeed, the $\mathrm{EBL}$ protect the fragile $\mathrm{C}_{60}$ from damage produced during electrode deposition onto the organic material. The profiles in figure 7 show that effectively there is some cathode metal diffusion into the organic under layer. Therefore, to protect efficiently the electron accepting layer, the EBL should be thick enough to prevent $\mathrm{C}_{60}$ contamination, since it is known that metal atoms present into the $\mathrm{C}_{60}$ behave as traps for electrons.

Accordance with table 3, high Rsh values are measured with BCP and CBBTZ. It means that these EBL are more efficient as protective layer from $\mathrm{Al}$ diffusion. They prevent conducting path formation, i. e. deep Al diffusion into the active layers of the cells. BCP, but also CBBTZ following our experiments, are highly sensible to their environment, mainly to oxygen, moisture... [4]. One possible hypothesis is that, since during evaporation, a significant percentage of $\mathrm{Al}$ is, at least, partly oxidized [19], these aluminium oxides can react with $\mathrm{BCP}$ or $\mathrm{CBBTZ}$ atoms, giving $\mathrm{Al}$-O-organic complex molecules, avoiding deep diffusion of $\mathrm{Al}$ up to $\mathrm{C}_{60}$.

If the EBL blocks the excitons and should be thick enough to protect the electron accepting layer, it should not block all charge carriers. Therefore the EBL should be chosen so that it allows electrons collection at the cathode. However, as the offset energy of the HOMO of the electron donor (often the fullerene) and the EBL (see table 2) is large and the optimum EBL thickness is around $8 \mathrm{~nm}$, which is too tick to allow high tunnelling current, the electrons must overcome a large energy barrier to reach the $\mathrm{Al}$ cathode in case of electron transport via LUMO levels (Figure 9-path1). The offset energy value of the LUMO level at the interface $\mathrm{C}_{60} / \mathrm{EBL}$ is significantly smaller with $\mathrm{CBBTZ}$ than with $\mathrm{Alq}_{3}$ (Figure 8), which can explain a better electron transmission towards the cathode and therefore the higher short circuit current. However, if such meaning is in good agreement with the good performances 
obtained with CBBTZ (LUMO 3.42) and the bad with butyl PB D (LUMO $2.5 \mathrm{eV}$ ) it cannot justifies the different behaviour of $\mathrm{Alq}_{3}$ and $\mathrm{BCP}$ which have the same LUMO $(3 \mathrm{eV})$.

More probably, the charge transport in the EBL is due to damage induced during deposition of the cathode, which introduces conducting levels below its LUMO (Figure 9path2) and explains the reason why the transport of electron is not weakened. [5]. The proposed complex Al-O-organic molecule can introduce energy levels in the band gap leading to conductive paths, which justifies the small Rs value of these structures.

\section{Conclusion}

After optical, electrochemical and XPS characterization a new material, the CBBTZ, has been probed as exciton blocking layer in organic solar cells.

When the CBBTZ is introduced as EBL in ITO/Au $(0.5 \mathrm{~nm}) / \mathrm{CuPc}(3.5 \mathrm{~nm}) / \mathrm{C}_{60} / \mathrm{EBL} / \mathrm{Al}$ devices, it allows achieving efficiencies of the same order of magnitude than those achieved with BCP and significantly higher than those obtained with butyl-PBD and $\mathrm{Alq}_{3}$. The different behaviours are discussed with the help of the different hypothe sis proposed to explain the effects of EBL.

As a conclusion, the EBL, not only block the excitons far from the cathode where they can be quenched, but also prevent from damage, during cathode deposition, the electron acceptor film. It should be transparent to the solar spectrum to act as a spacer between the photoactive region and the metallic cathode and it must transport electrons to avoid high series resistance. This last property can be achieved through EBL conductive properties modification during cathode deposition as shown by the direct evidence of aluminium diffusion into the buffer layer.

Acknowledgements: This work has been supported by the France-Chili contract ECOSCONICYT ${ }^{\circ}$ C09E02. Dr. YAPI Abé would like to thank University Agency of La Francophonie (AUF) for financial support (Postdoc scholarship). 


\section{References:}

[1] S S. Braun, W.R. Salaneck, M. Fahlman, Energy-level alignment at organic/metal and organic/organic interfaces, Adv. Mater. 21 (2009) 1450-1472.

[2] J. Huang, J. Yu, H. Lin, Y. Jian g, Detailed analysis of bathocuproine layer for organic solar cells based on copper phthalocyanine and C60, J. Appl. Phys. 105 (2009) 0773105. [3] P. Peumans, V. Bulovic, S.R. Forrest, Efficient photon harvesting at high optical intensities in ultrathin organic double-heterostructure photovoltaic diodes, Appl. Phys. Lett. 76 (2000) 2650.

[4] Q.L. Song, F.Y. Li, H. Yang, H.R. Wu, X.M. Ding, C.H. Huang, X.Y. Hou, Smallmolecule organic solar cells with improved stability, Chem. Phys. Lett. 416 (2005) $42-46$ [5] B B.P. Rand, J. Li, J. Xue, R.J. Holmes, M.E. Thompson, S.R. Forrest, Adv. Mater., Organic double-heterostructure photovoltaic cells employing thick tris(acetylacto)ruthenium(III) exciton-blocking layers, 17 (2005) 2714-2718.

[6] Z.R. Hong, Z.H. Huang, X.T. Zeng, Investigation into effects of electron transporting materials on organic solar cells with copper phthalocyanine/C60 heterojunctions, Chem. Phys. Lett. 425 (2006) 62-65.

[7] Y. Berredjem, N. Karst, A. Boulmokh, A. Drici, J.C. Bernède, Optimis ation of the interface "organic material/aluminium" of $\mathrm{CuPc} / \mathrm{C}_{60}$ based photovoltaic cells, The European Physical Journal: Applied Physics 40 (2007) 163 -167.

[8] F. Brovelli, M.A. del Valle, F.R. Díaz, J.C. Bernède, Electrochemical and optical studies of 1,4-diaminoanthraquine for solar cells applications, Bol. Soc. Chil. Quim. 46 (2001) 319. M. A. del Valle, G. M. Soto, L. I. Canales, F. R. Díaz, J. C. Bernède, e -Polymers 60 (2008) 1. [9] G. A. East, M. A. del Valle, J. Chem. Ed. 77 (2000) 97.

[10] J.C. Bernède, Y. Berredjem, L. Cattin, M. Morsli, Improvement of organic solar cells performances using a zinc oxide anode coated by an ultra thin metallic layer. Appl. Phys. Lett. $92(2008) 083304$.

[11] J. C. Bernède, L. Cattin, M. Morsli, Y. Berredjem, Ultra thi n metal layer passivation of the transparent conductive anode in organic solar cells Solar Energy Materials and Solar Cells, 92 (2008) 1508-1515.

[12] R. G. Gordon : Proceedings of the Material Research Society Symposium, Vol. 426, Material Research Society, 1996, p. 419.

[13] S. Kasmi, A. Djafri J. Hamelin , L. Paquin, J.P. Bazureau, M. Rahmouni, Communication of Synthetic Organic chemistry (2007) 37-41. 
[14] F. Salzman, J. Xue, B.P. Rand, A. Alexander, M.E. Thompson, S.R. Forrest, The effects of copper phthalocyanine purity on organic solar cell performance, Organic Electronics 6 (2005) 242-246.

[15] Y. Choe, S.Y. Park, D.W. Park, W. Kim, Influence of a stacked-CuPc layer on the performance of organic light-emetting diodes, Macromolecular research 14 (200 6) 38-44.

[16] A. Latef, J.C. Bernède, Study of the thin film interface Aluminium -Tellurium , Phys. Stat. Sol. (a) 124 (1991) 243-252.

[17] D. M. de Leeuw, M. M. J. Simenon, A. R. Brown, R. E. F. Einerhand, Synth. Met., Stability of n-type doped conducting polymers and consequences for polymeric microelectronic devices, 87 (1997) 53-59.

[18] B. Brousse, B. Ratier, A. Moliton, Vapour deposited solar cells based on $\mathrm{CuPc}-\mathrm{C}_{60}$ single heterojunction: optimization of the deposition process, Synth. Met. 147 (2004) 293-298.

[19] J. Kim, J.J. Weiner, M. Zukic, D.G. Torr, J. Vac. Sci. Technol. A12 (1994) 3062. 


\section{Scheme}

Scheme 1: 5-(4-chlorobenzylidene) (CBTTZ)

\section{Figures}

Figure 1: Cyclic voltammetric profiles of CBBTZ in $\mathrm{CH}_{2} \mathrm{Cl}_{2}$. (a) Between $E_{\mathrm{c}}=0 \mathrm{~V}$ and $E_{\mathrm{a}}=2.5 \mathrm{~V}$. (b) Between $E_{\mathrm{c}}=-1.5 \mathrm{~V}$ and $E_{\mathrm{a}}=0 \mathrm{~V}$. Interface: $\mathrm{Pt} \mid 0.001 \mathrm{~mol} \cdot \mathrm{L}^{-1} \mathrm{CBBTZ}+0.1$ $\mathrm{mol} \cdot \mathrm{L}^{-1} \mathrm{TBAPF}_{6}$. Scan rate $0.008 \mathrm{~V} \cdot \mathrm{s}^{-1}$.

Figure 2: Transmission (optical density) spectrum of CBBTZ thin film (100 nm) (at room temperature).

Figure 3: XPS spectra of CBBTZ thin film (a) C1s, (b) O1s, (c) S2p, (d) N1s, (e) Cl2p.

Figure 4: variation of the energy conversion efficiency of the cells with the thickness of the CBBTZ buffer layer thickness.

Figure 5: Typical I-V characteristics of organic solar deposited at the same time, using different buffer layers at the interface electron acceptor/electron donor.

Figure 6: XPS depth profile of CBBTZ (a) and butyl-PBD (b) buffer layer.

Figure 7: Decomposition of the A12p peak.

Figure 8: Band scheme before contact of the or ganic solar cells with the different buffer layers probed at the interface cathode/ organic material.

Figure 9: Band schemes of organic films and cathode contact.

\section{Tables}

Table 1: Typical parameters of organic solar cells with, or not, different buffer layers.

Table 2: Rs and Rsh values estimated from the experimental curves of figure 5.

Table 3: HOMO and LUMO values of the different buffer layers used in the present work. 


\begin{tabular}{ccccc}
\hline Buffer Layer & Voc $(\mathrm{V})$ & $\mathrm{Jcc}\left(\mathrm{mA} / \mathrm{cm}^{2}\right)$ & $\mathrm{FF}$ & $\mathrm{\eta}(\%)$ \\
\hline \multirow{2}{*}{ No BL } & 0.37 & 2.00 & 0.36 & 0.27 \\
\hline \multirow{2}{*}{ Alq3 } & 0.535 & 5.21 & 0.54 & 1.50 \\
& 0.505 & 4.97 & 0.58 & 1.46 \\
\hline \multirow{2}{*}{ CBTTZ } & 0.525 & 6.35 & 0.60 & 1.99 \\
& 0.525 & 6.25 & 0.60 & 1.98 \\
\hline \multirow{2}{*}{ Butyl-PBD } & 0.51 & 3.67 & 0.33 & 0.63 \\
& 0.51 & 2.52 & 0.38 & 0.49 \\
\hline \multirow{2}{*}{ BCP } & 0.505 & 6.70 & 0.59 & 2 \\
& 0.495 & 7.03 & 0.60 & 2.07 \\
\hline
\end{tabular}

Table 1

\begin{tabular}{lll}
\hline EBL & Rs $(~)$ & Rp $($ ) \\
\hline BCP & 128 & $19.6 \mathrm{k}$ \\
\hline CBTTZEN & 133 & $33 \mathrm{k}$ \\
\hline Butyl PBD & 299 & $7.2 \mathrm{k}$ \\
\hline Alq $_{3}$ & 384 & $10.4 \mathrm{k}$ \\
\hline
\end{tabular}

Table 2

\begin{tabular}{cccc}
\hline Organic buffer layer & HOMO $(\mathrm{eV})$ & LUMO $(\mathrm{eV})$ & $\mathrm{Eg}(\mathrm{eV})$ \\
\hline $\mathrm{Alq}_{3}$ & 5.9 & 3 & 2.9 \\
\hline CBBTZ & 6.42 & 3.42 & 3 \\
\hline butyl-PBD & 6.5 & 2.5 & 4 \\
\hline BCP & 6.5 & 3 & 3.5 \\
\hline
\end{tabular}

Table 3 


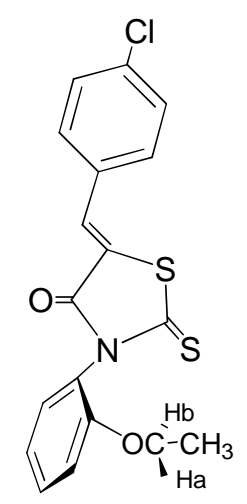

Scheme 1.
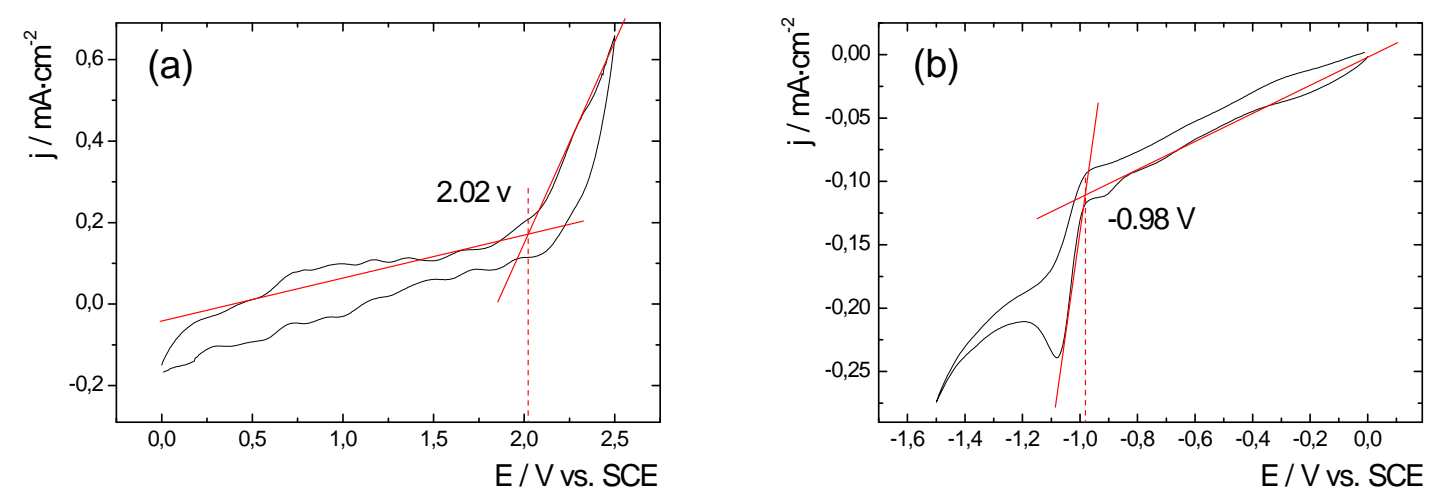

Figure 1

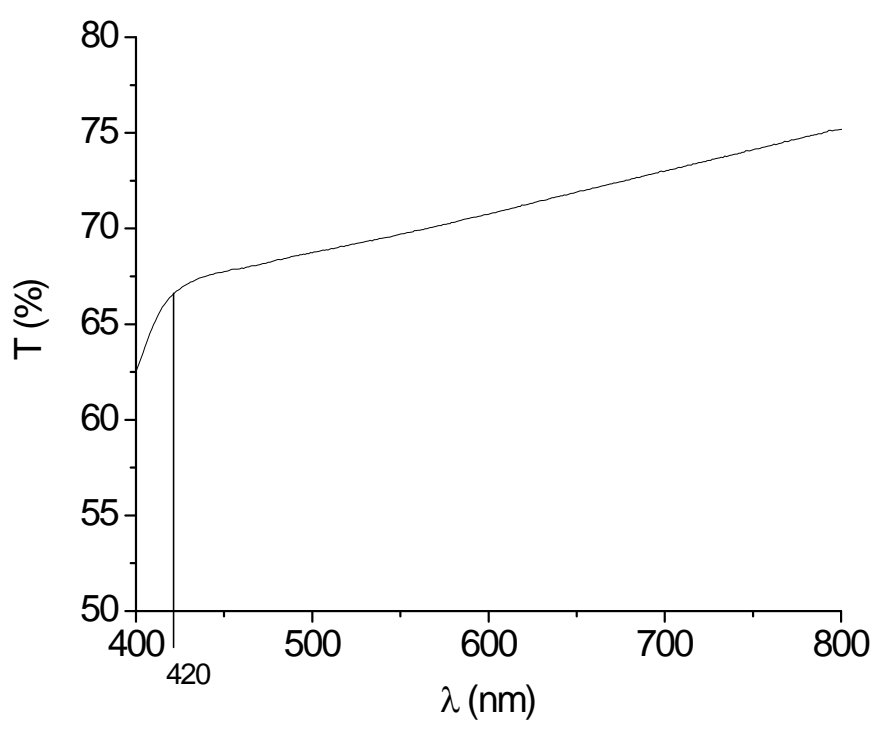

Figure 2. 

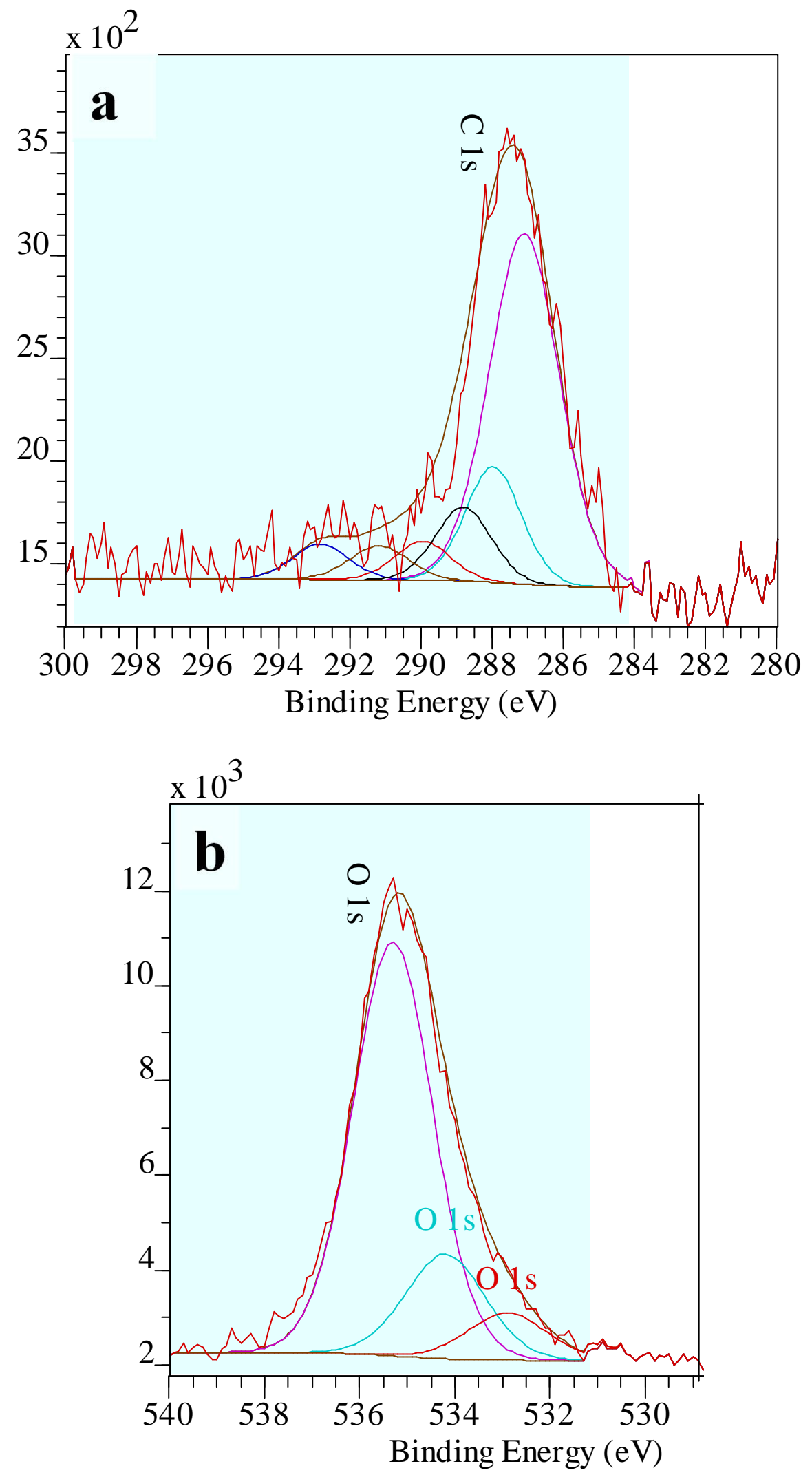

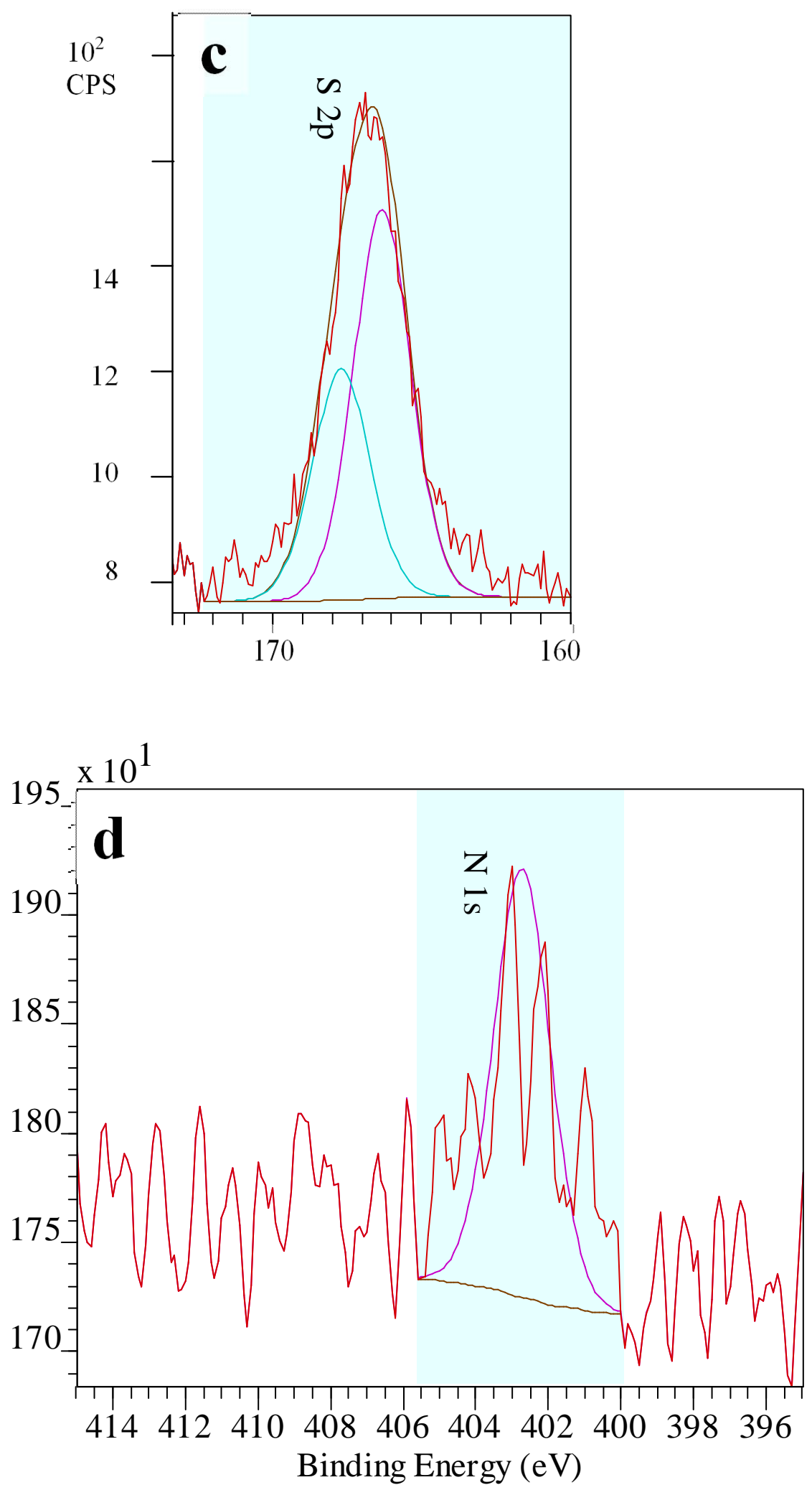


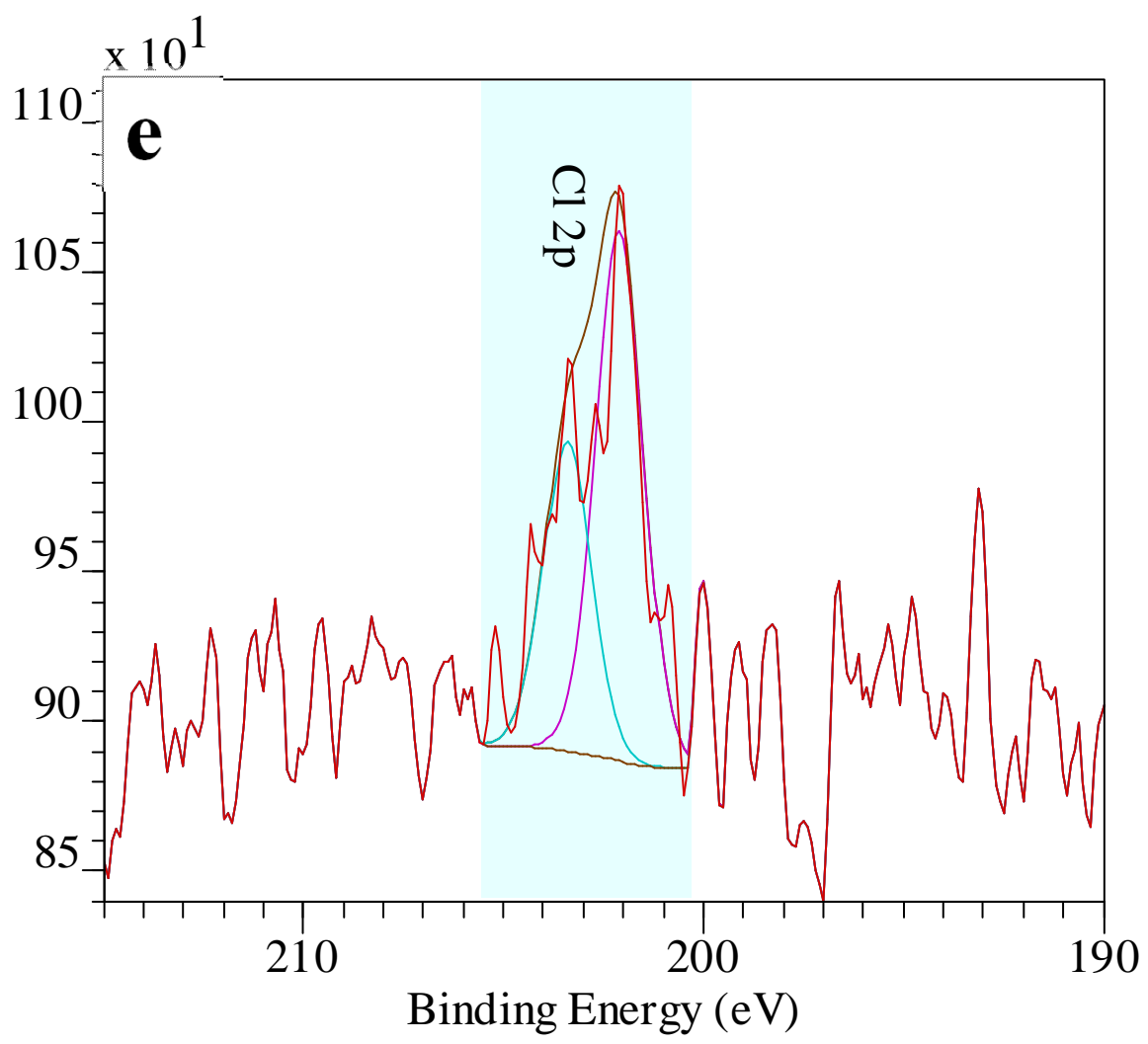

Figure 3 


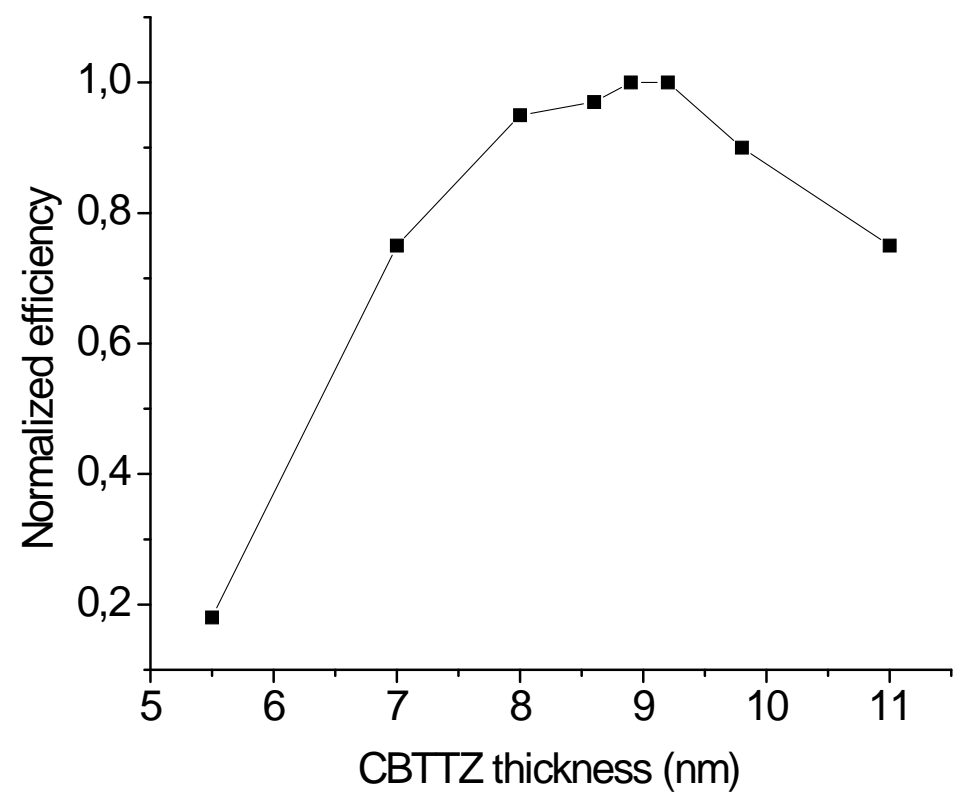

Figure 4.

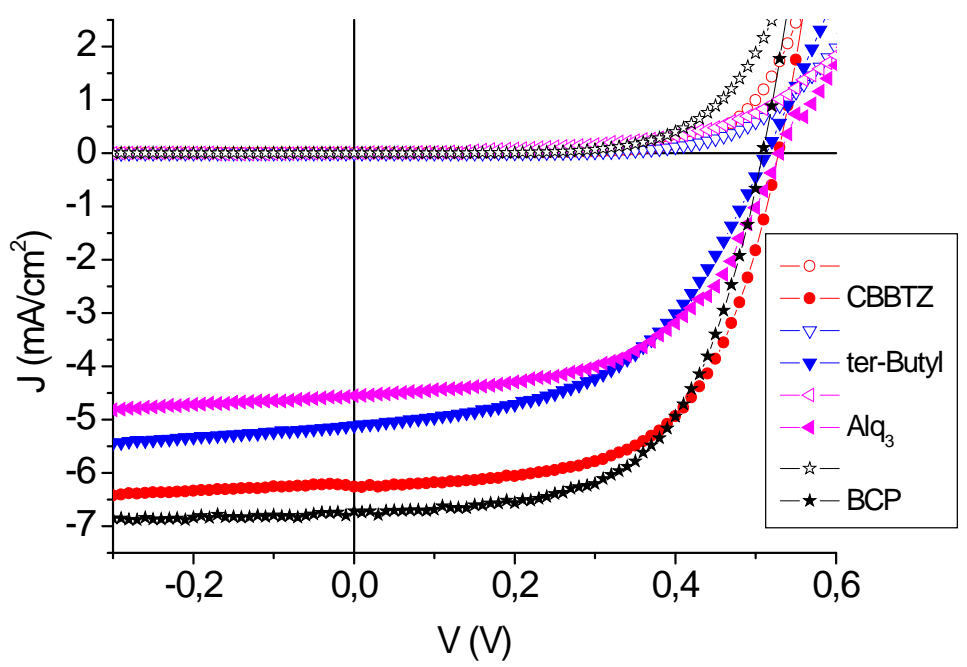

Figure 5. 

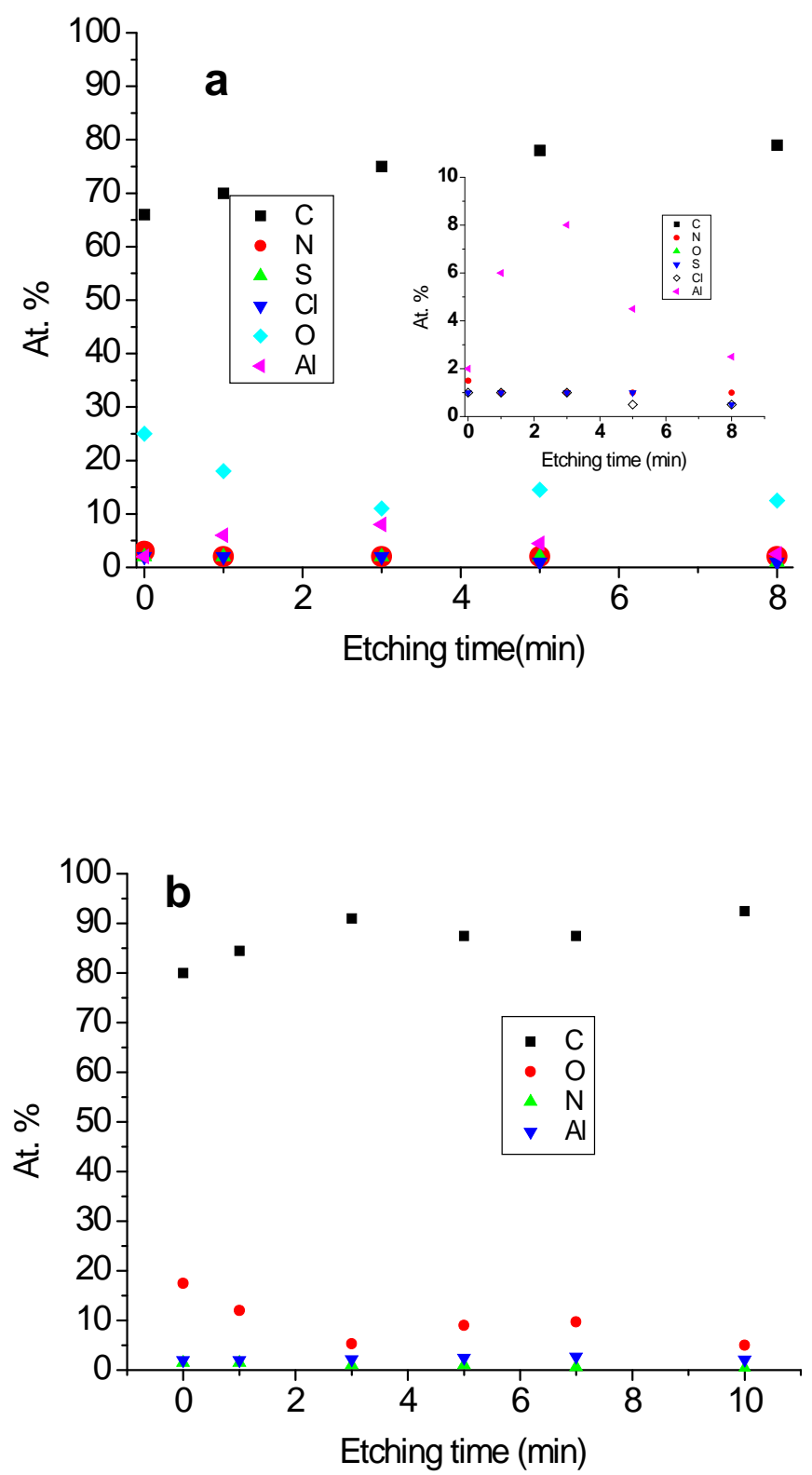

Figure 6. 


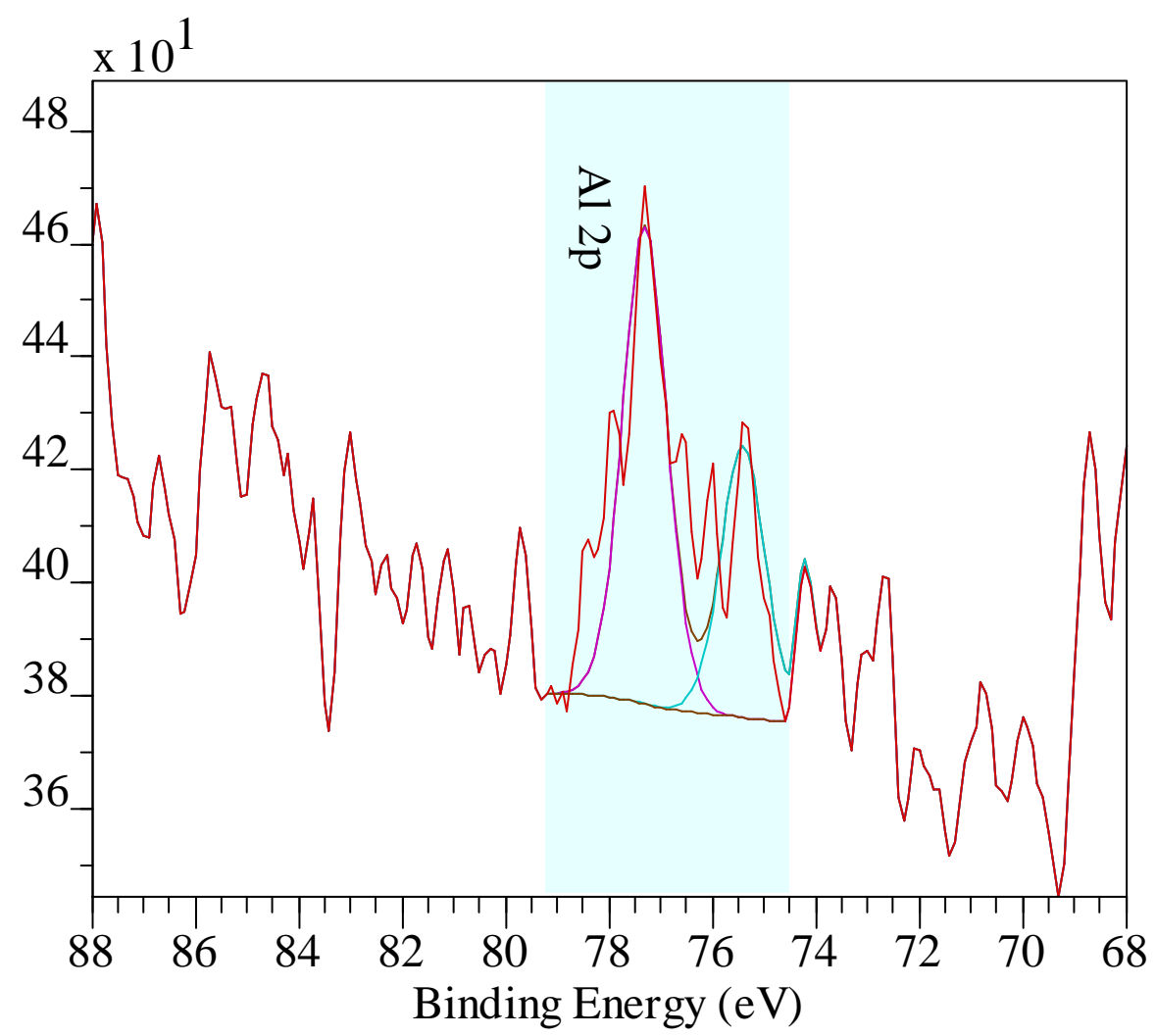

Figure 7. 


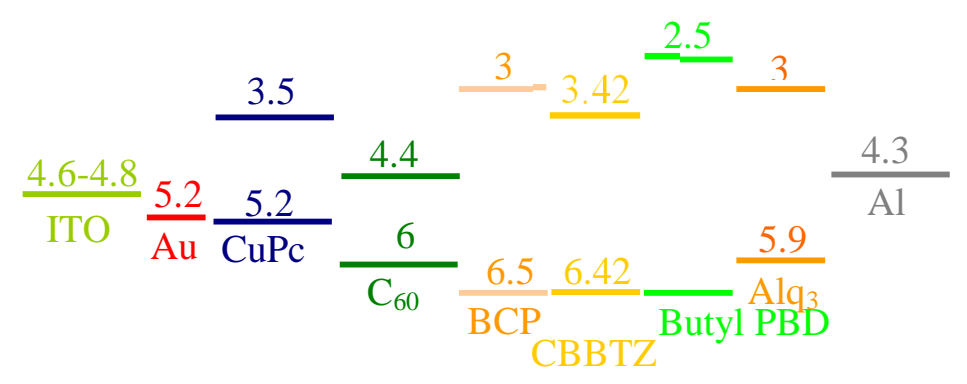

Figure 8

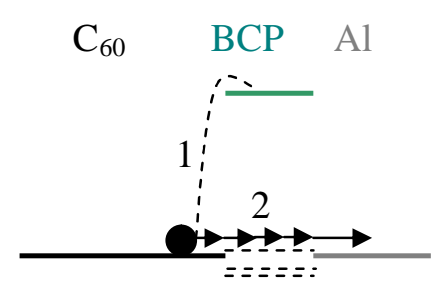

Figure 9 